\section{ROAD KILL FREQUENCIES}

by RICHARD L. COULTON*

In the June, 1975, Blue Jay, James Donovan reported wildlife road kills near Whitewood, Saskatchewan, during July, 1974.' In a distance of 560 miles, 112 individual kills were observed, averaging 1 kill per 5 miles.

After reading Donovan's paper, I wondered how applicable this rate was throughout the Prairie Provinces and I tested this in August, 1975, by having an observer in the car with me note wildlife kills as we travelled western Alberta highways. Table 1 indicates the routes taken, dates, mileage and number of kills observed.

Since some observed kills would have occurred the previous day, it is to be expected that our road kill frequency would be somewhat greater than Donovan's, provided, of course, that his indicated rate of one per 5 miles is fairly typical. This proved to be close to our findings: one per 3.9 miles. The results of our observations are given in Table 2 .

It is of interest to note that, in both cases, ground squirrels constitute the largest single group of fatalities, while in our study crows formed a much greater percentage of the total $(15 \%)$ than in Saskatchewan (3\%).

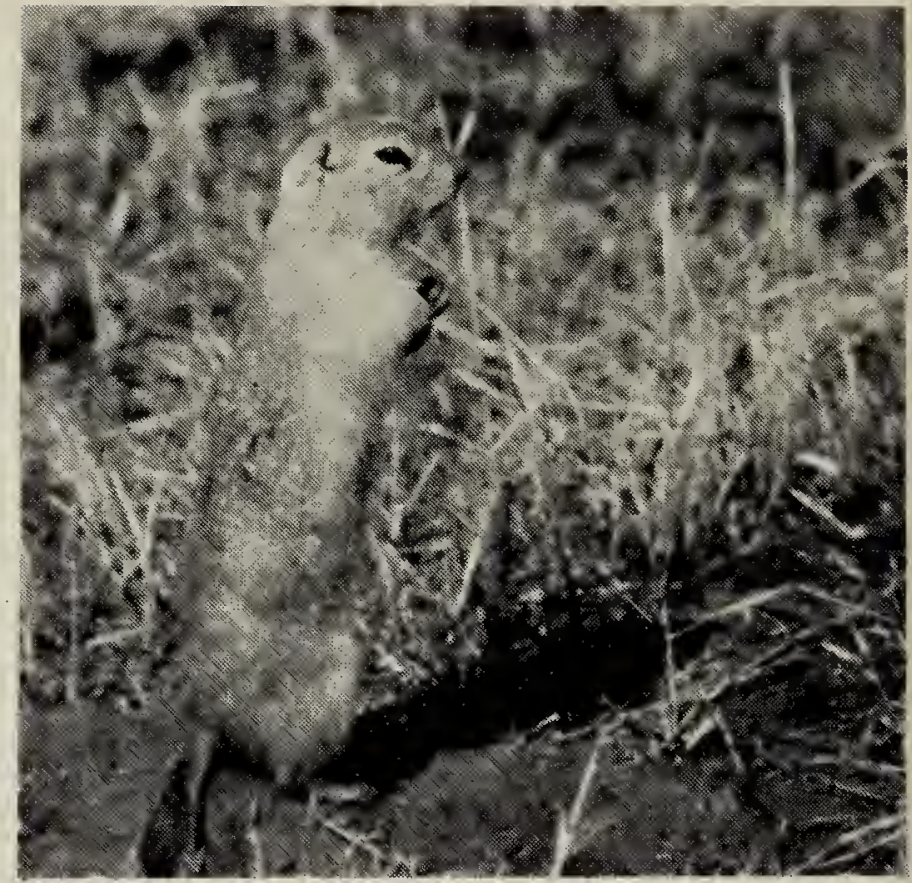

Richardson's Ground Squirrel.

G. W. Seib

It is highly probable that, like Donovan, I also missed a considerable number of individuals which may have been knocked off the road, or were eaten before being observed, or disintegrated. I feel that the true rate of wildlife mortality on highways is far higher than these observations suggest.

My observations suggest that Donovan's sample was indeed a typical one, and that the frequency of road kills throughout the prairies is commonly in excess of an average of one kill per 5 miles each day.

Table 1

HIGHWAYS OBSERVED IN WESTERN ALBERTA

Route

Bentley - Lacombe

Miles

Lacombe - Stettler

Lacombe - Alix .................... 28

Sylvan Lake - Bentley .................. 11

Sylvan Lake - Bentley ................... 11

Sylvan Lake - Bentley .................... 11

Sylvan Lake - Eckville ................... 14

TOTALS
Number o. Kills Observec

Date

August $5 \quad \ldots \ldots \ldots 9$

August $5 \ldots \ldots 12$

August $13 \ldots \ldots 3$

August $21 \quad \ldots \ldots .4$

August $27 \ldots \ldots$.

August $29 \quad \ldots \ldots . .4$

August $31 \ldots \ldots .2$

August $31 \ldots . . .4$

${ }^{*}$ Bentley, Alberta.

TOC OJO 
Table 2

ROAD KILLS IN WESTERN ALBERTA

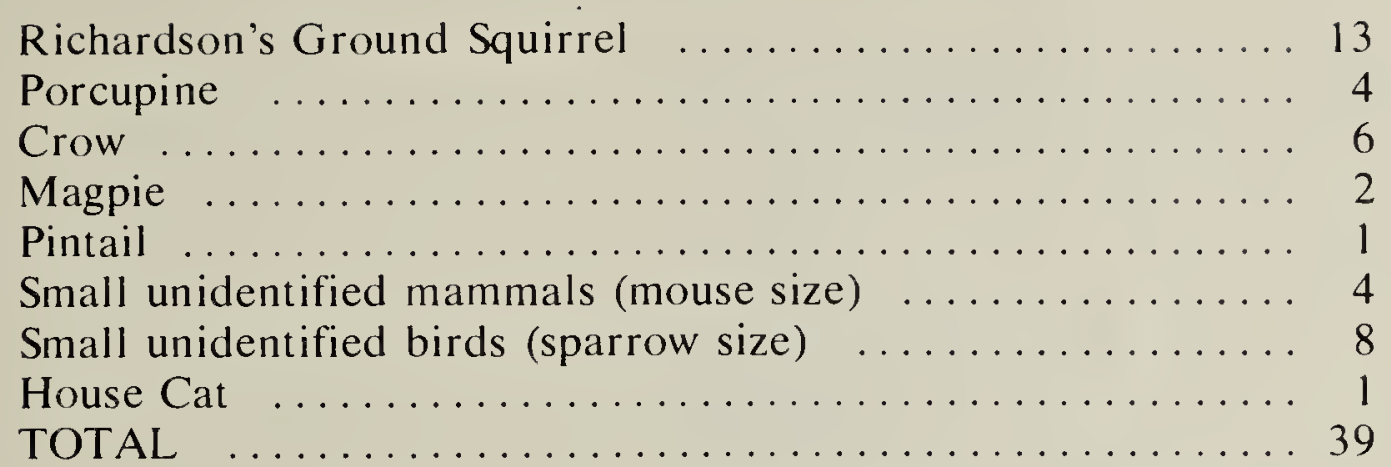

I would like to thank Doris Coulton of Bentley and Cameron MacGregor of Red Deer for acting as observers on some of the journeys involved.
'DONOVAN, JAMES. 1975. Wildlife Road Kills. Blue Jay 33:120.

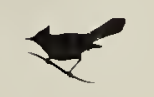

\section{1 期arg Añ}

From the October-December, 1945, Blue Jay comes the following report by Cliff Shaw, entitled, "A Wasp Episode":

On the Labour Day weekend, while hunting arrowheads on a sand blow along the Assiniboine, we watched one of the digger wasps hard at work.

When first noted the wasp had just begun to excavate a vertical shaft in the fine loose sand. The insect, black and scarcely half an inch in length, was rapidly digging similar to the manner in which a dog digs for a gopher. Working from one spot, the sand flew from between her front feet and was tossed fully 3 to 4 inches behind her, over the edge of the hole. As the incline became more steep and sand tumbled to the bottom of the hole, she would run backwards up the side and begin a new trough about an inch from the rim.

When the funnel-shaped hole was about 3 inches deep, and approximately the same in diameter, the wasp uncovered a smooth green caterpillar, apparently still alive.
Turning the larva over on its side the wasp grasped it by the head and pressed her abdomen against its thorax. We could not observe whether the wasp was administering a sting to paralyse the larva or was depositing an egg. This action was repeated several times.

Although the caterpillar was many times her own weight and over an inch in length, the wasp dragged it out of the hole. Then she got astride it! The wasp reminded us of a small plane with an oversized bomb load, the caterpillar being almost three times her own length.

By some unseen method the larva was underslung to the body of the wasp - probably being held in her strong mandibles. Running on all legs, the wasp struck out rapidly across the sand blow. Whenever she met an obstruction in her path she would drop the caterpillar and scout the possibilities of an easier route. At every 10 or 15 feet she would stop for a rest, remaining astride the larva.

After watching the wasp carry her heavy load for 40 or 50 feet, we lost sight of her when she ran into a clump of grass. 